\title{
断面内で応力が急変する場合の切抜き法による 表面残留応力の測定精度*
}

\author{
渡辺正紀**渡召寛***
}

\author{
Accuracy of Measurement of Residual Surface Stress \\ by Drilled-Out Method under Varying Condition of \\ Stress Distribution in the Section*
}

By Masaki Watanabe** and Hiroshi Watanabe***

\begin{abstract}
A stainless clad material very often suffers considerable change of its residual stress distribution near the boundary between the stainless and the mild steel, and the following results was obtained from the analysis of as well as experiments on the accuracy of the surface stress as determined by the completely relaxed method like a drilled-out method, trepanning method, etc. under the above mentioned residual stress condition.

(1) The surface stress of a stainless section almost completely relaxes and shows a true value when the ratio of the thickness of a strainless section to a drilled-out inner diameter is approximately $1 / 3$ or more.

(2) The determined value is less than the true value, when this ratio is less than $1 / 3$, and it suggests that other methods may be applied.
\end{abstract}

\section{1. 緒言}

最近オーステナイトステンレスクラッド鋼が広く使用 されるすう勢にあるが，オーステナイトステンレス鋼

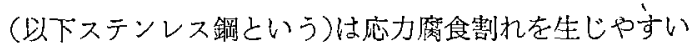
金属であるため，ステンレス釦表面残留応力の小さい状 態で使用すべきである.したがって著者らはステンレス クラッド鋼老用いた溶接構造物の残留応力の発生状況, 督減法あるいは荷㗢時の応力状態などについて解析的研 究を実施しているが゚-3)，表面残留応力の測定法屯重要 な命題の一つとしている.

すなわちステンレスクラッド鋼は製作あるいは加工に 際して高温に加熱する場合が多く，ステンレス銅と軟鋼 両材の線膨脹係数が哄なるため，常温冷却時に残留応力 を生じ，乙の残留応力は雨材の断面内境界部で大きさが 急激に変化する3． また溶接部において屯溶接線值角方 向に㥂いて類似の応力状態にあることが多い1，本報で はかかる応力状態にあるステンレスクラッド鋼に対して ステンレス鏋の表面残留応力切抜き法4), トレパニン

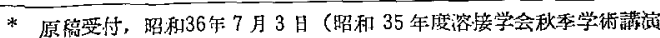
会に括的七热表)

** 开圆, 大阪火学工学部 Member, Faculty of Engineering, Osaka University

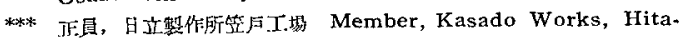
chi, Ltd.
グ法らなどの全解放法で测定する際の測定精度について 考察をおこない，测定简所の応力がほぼ完全にち綏され るためのステンレス鑘限界厚さを求めるととを試みた。

\section{2. 理論解析}

\section{1 解析の対象しする模型}

精度の検討にあたって重要な量は真の残留応力值に対 する応力ち緩量の割合であるため，簢単のため一次元応 力状態について考察をおこなうこととし，クラッド鋼の 表面に対し直角に切出した Fig. 1 のごとき薄く長いク ラッド鋼を一様に加熱, 冷 却した模型を考察の対象上 する.すなわちかかる処理 によって両材の境界部で大 きさの急変する応力状態を 得ることができるが，とれ にステンレス銅側表面より

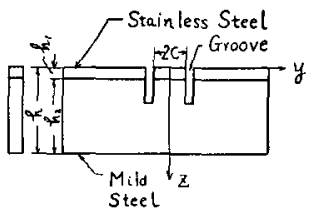

Fig. 1 Model for stress analysis
図のごとき淟を入れた場合の 2 本の溝間の表面残留応力 のち綬量を考察する. 解析にあたっては簡単のため両材 の線膨脹係数以外の機械的, 物理的性質を同一七し, そ の温度依存性を無視し，加つ完全弾塑性体と考元る。

\section{2 初期残留応力分布}

Fig. 1 に示す薄く長いステンレスクラッド鋼を一様

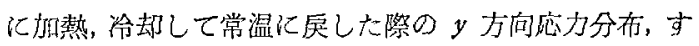


なわち板の初期残留応力分布を求める．解析にさきだち つぎの記号を定める.

添字 1,2 ；ステンレス鋼部，軟鋼部を示す。

添字 $a, b, c$; 加熱前, 加熱時, 常温冷却時の值

$\varepsilon^{t}, \varepsilon^{e}, \varepsilon^{p}, \varepsilon^{0} ;$ 全ひずみ，㧛性ひずみ，望性ひずみ，

固有ひずみ

$\sigma$; 霍直応力, $\tau$ ；せ九断応力

$\varepsilon_{0}, Y ;$ ，一軸引張降伏ひずみ，応力

$E$; 弾性係数

$F, M$ : 単位幅の板に作用する軸力，曲げ拘束モーメ ント

廿, $\phi$; 板の $z=0$ におりるひずみおよび曲率

$y, z ;$ Fig. 1 亿示す座標

$h$; 板厚, $\theta$; 温度, $\alpha$; 線膨脹係数

加熱前における応力，ひずみ間に成立する関係式は

$$
\begin{aligned}
& \left.\begin{array}{l}
\varepsilon_{a}^{t}=\varepsilon_{1 a}^{e}+\varepsilon_{1 a}^{p}+\varepsilon_{1}^{0}+\alpha_{1} \theta_{a} \\
\varepsilon_{a}^{t}=\varepsilon_{2 a}^{e}+\varepsilon_{2 a}^{p}+\varepsilon_{2}^{0}+\alpha_{2} \theta_{a}
\end{array}\right\} \\
& \sigma_{1 a}=E \varepsilon_{1}{ }^{e}{ }_{a}, \sigma_{2 a}=E \varepsilon_{2}{ }^{e} a \\
& \int_{0}^{h_{1}} \sigma_{1 a} d z+\int_{h_{1}}^{h} \sigma_{2 a} d z=F_{a} \\
& \left.\int_{0}^{h_{1}} \sigma_{1 a} z d z+\int_{h_{1}}^{h} \sigma_{2 a} z d z=M_{a}\right\}
\end{aligned}
$$

亡なり, 板の $y$ 方向全ひずみは $\boldsymbol{z}$ 方向に直線分布をす ると考えてよいので

$$
\varepsilon_{a}^{t}=\psi_{a}+\phi_{a} z
$$

が成立する.

加熱時における応力, ひずみ関係式は添字 $a$ の代わり にb代入すれば上と全く同一の形式で表示できる。一 般にステンレスクラッド鏔では $\alpha_{1}>\alpha_{2}$ で， $h_{1} \ll h$ なる ゆえ，片に特に大きな分布の变化がなく，かつ一般の溶接 構造物化見ら机るように温度変化の過程において $F, M$ に大きな変化がなりれば，加熱によってステンレス鋼部 にのみ圧縮降伏を生ずる，ステンレス鋼部全域が王縮降 伏を生ずるための限界温度は，最後に圧縮降伏する点を $z^{\prime}\left(0 \leqq z^{\prime} \leqq h\right)$ として, (1) ( (4) 式の添字 $a$ を $b$ と した式の（1），(4) 式において

$$
z=z^{\prime} \text { で } \varepsilon_{1 b}^{p}=\varepsilon_{2 b}^{p}=0, \quad \varepsilon_{1}^{e}=-\varepsilon_{0} .
$$

(2), (3) 式に拉いて

$$
\sigma_{1 b}=-E \varepsilon_{0}
$$

を代入すれば求めることができる。

さらに温度が上昇すれば応力分布は変化しないが $0 \leqq$ $z \leqq h_{1}$ 間の塑性ひずみ量は增加し，その大きさは（1） (4) 式の添字 $a$ を $b$ 上小た式で

$$
\varepsilon_{1 b}^{e}=-\varepsilon_{1}^{0}, \quad \varepsilon_{2 b}^{p}=0 .
$$

とおけば求めるこらができる。
かかる状態にあるむのを一様に冷却すれば，高温時に 生じた塑性ひずみ量を固有ひずみ最として付加すればよ いので

$$
\left.\begin{array}{l}
\varepsilon_{c}^{t}=\varepsilon_{1 c}^{g}+\varepsilon_{1 c}^{p}+\varepsilon_{1}^{0}+\varepsilon_{1 b}^{p}+\alpha_{1} \theta_{c} \\
\varepsilon_{c}^{t}=\varepsilon_{2 c}^{g}+\varepsilon_{2 c}^{p}+\varepsilon_{2}^{0}+\alpha_{2} \theta_{c}
\end{array}\right\}
$$

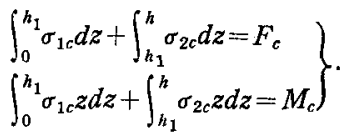

$\varepsilon_{c}^{t}=\psi_{c}+\phi_{c} z$

の関係式が成立し，一般にステンレス鋼部の応力は引引張 応力之なり，古る限度以上に加熱したものを常温まで冷 却すれば，ステンレス鋼部に引張降伏を生ずる、ステン

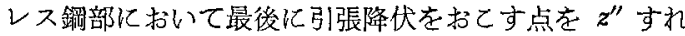
ば，ステンレス鋰部全域に引張降伏をおてさせるための 最低加熱温度住

$$
z=z^{\prime \prime} \text { において } \varepsilon_{2 c}^{\ell}=\varepsilon_{0}, \varepsilon_{1 c}^{p}=\varepsilon_{2 c}^{p}=0 \text {. }
$$

とおくことによって求めうる. ての温度以上に加熱して 常温冷却した際の応力は（12）式の条件で得られる応力 分布と全く同一である。

一般の構造物でもっとも多く喈遇する拘束条件は，全 過程を通じて曲げに対する拘束はあるが，軸力の拘束は 小さい場合である．したがっててこでも軸力の拘束を無 視し，曲げに対しては拘束の両極端の場合，すなわち助 湾形が完全に拘束される場合，および拘束の全然ない 場合について問題をとり扱かうことにする，また簡単の ため初期状態の固有ひずみ $\varepsilon_{1}^{0} ， \varepsilon_{2}^{0}$ をそれぞれの籁囲内 で一様に分布するものとする。

2.1 .1 曲价変形完全拘束の場合

初期状態において塑性ひずみは 0 と見なし得，かつ明 げ変形を生じないので

$$
\phi_{a}=\phi_{b}=\phi_{c}=0
$$

となり，モーメントの釣合条件式は不要となる。したが つて $\theta_{c}=\theta_{a}$ 考慮して上の方法に上り加熱冷却後の残 留応力分布を求め机ば $h_{1} / h \leqq 0.5$ の上き

に加熱した後冷却すれば

$$
\theta_{b}-\theta_{a} \geqq 2 \frac{h}{h_{2}} \frac{\varepsilon_{0}}{\alpha_{1}-\alpha_{2}} \quad\left(\frac{h_{1}}{h} \leqq 0.5\right)
$$

$$
\begin{array}{ll}
0 \leqq z<h_{1} & \sigma_{y}=Y \\
h_{1}<z \leqq h & \sigma_{y}=-\frac{h_{1}}{h_{2}} Y
\end{array}
$$

となる。

この際は $h_{1} \ll h$ の条件を必ずし屯必要とせず $h_{1} / h \geqq 0.5$ のとき 
$\theta_{b}-\theta_{a} \geqq 2 \frac{h}{h_{1}}-\frac{\varepsilon_{0}}{\alpha_{1}-\alpha_{2}}$

に加熱した後冷却すれば

$$
\begin{array}{ll}
0 \leqq z<h_{1} \text { て } & \sigma_{y}=\frac{h_{2}}{h_{1}} Y \\
h_{1}<z \leqq h & \multicolumn{2}{c}{\sigma_{y}=-Y}
\end{array}
$$

の応力が残留する。

Fig. 2 は $h_{1} / h=0.1$ の際 の残留応力分布の計算例であ る. モーメントは曲牧拘束モ ーメントと釣合うため，図で は釣合っいない。

\section{2 .2 曲计拘束のない} 埸合

$h_{1} / h<0.18$ の範围で $F=0$, $M=0$ とおき，前式の計算を おこなえば

$$
\theta_{b}-\theta_{a} \geqq 2 \frac{1+\frac{h_{1}}{h}+4\left(\frac{h_{1}}{h}\right)^{2}}{\left(\frac{h_{2}}{h}\right)^{3}} \frac{\varepsilon_{0}}{\alpha_{1}-\alpha_{2}}
$$

の加熱後冷却に対し，常温時の残留応力は

$$
\left.\begin{array}{rl}
0 \leqq z<h_{1} \text { で } & \sigma_{y}=Y \\
h_{1}<z \leqq h \text { で } \quad \sigma_{y} & =\left(\frac{h}{h_{2}}\right)^{2} \frac{h_{1}}{h_{2}}\left[-\left\{4+\frac{h_{1}}{h}\right.\right. \\
& \left.\left.+\left(\frac{h_{1}}{h}\right)^{2}\right\}+6 \frac{z}{h}\right] Y
\end{array}\right\}
$$

Fig. 2 An example of calculated initial residual stress distribution (Completely constrained for ben ding distorsion)

で与えられる. $h_{1} / h=0.1$

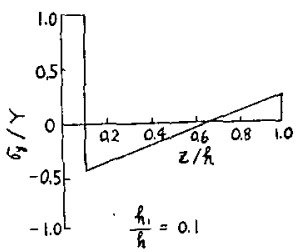

Fig. 3 An example of calculated initial residual stress distribution (No constraint)

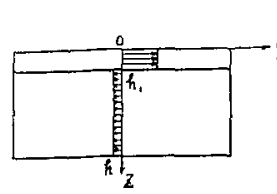

(a) の婸合の応力分布を Fig. 3 に示したが、ステンレス鋼 部は一様引張降伏応力, 軟 鋼部にはとれに釣合う弾性 忍力が残留している.

2.3 切抜きによるち 緩応力

2.3 .1 曲げ変形完全 拘束の場合

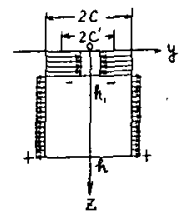

(b)

Fig. 4 Schemata for relaxed stress calculation

いまFig. 4 (a) のどとく残留応力を有する長いく形 ・板を(b）のごとくある幅 $2 c$ で切抜いた際のステンレ 又鋼表面での残留応力のち緩量を求める。切抜きのため のち緩応力は（b）において切抜き面 $(y= \pm c)$ に最初 の残贸応力と逆方向の垂直応力を作用させたときのステ
ンレス鋼例表面（ $z=0 ）$ の応力の符号を変えたものに等 しい（ち緩量としては応力が最初の状態上り減少するも のを正とするため).すなわち形式的には残留応力と同 一の垂直応力を切抜き面に作用させた時に生ずる応力が ち緩応力となる。

したがって

$$
\left.\begin{array}{c}
h_{1} / h \leqq 0.5 \text { のとき } \\
z= \pm c \text { において } \quad \tau^{\prime} y_{z}=0 \\
0 \leqq z<h_{1}, \quad \sigma y^{\prime}=Y \\
h_{1}<z \leqq h, \quad \sigma^{\prime}=-\frac{h_{1}}{h_{2}} Y \\
z=0, h \text { において } \quad \sigma_{z}^{\prime}=0, \tau_{y_{z}=0}^{\prime}
\end{array}\right\}
$$

(ここに゙を付したのは初期に存在していた㐫力と区別 するためである.)

$$
\begin{aligned}
& h_{1} / h \geqq 0.5 \text { のとき } \\
& y= \pm c \text { において } \quad \tau^{\prime} y_{z}=0 \\
& 0 \leqq z<h_{1}, \quad \sigma_{y}^{\prime}=\frac{h_{2}}{h_{1}} Y \\
& h_{1}<z \leqq h, \quad \sigma_{y^{\prime}}=-Y \\
& z=0, h \text { において } \sigma_{z}^{\prime}=0, \quad \tau^{\prime} y_{z}=0
\end{aligned}
$$

の境界条件の屯とでく形板内の応力分布を求める，この 一般解については従来より多くの解析が行なわれている が6)，高次の行列式を解く必要があり計算が非常に煩雑 となる.したがってててでは $z=0, h$ の面の境界条件 を完全には満足しないが， $y= \pm c$ の境界条件を半区間 フーリエ級数であらわし，Timoshenko7) にしたがって $y$ 方向ち綬応力 $\sigma^{\prime} y$ を導けぱ

$$
\begin{aligned}
& \frac{h_{1}}{h} \leqq 0.5 \text { のとき } \\
& \frac{\sigma^{\prime} y}{Y}=\frac{4}{\pi} \frac{h}{h_{2}} \sum_{n=1}^{\infty} F_{1 n} \\
& \frac{h_{1}}{h} \geqq 0.5 \text { のとき } \\
& \frac{\sigma y^{\prime}}{Y}=\frac{4}{\pi} \frac{h}{h_{1}} \sum_{n=1}^{\infty} F_{1 n}
\end{aligned}
$$

ただし

$$
\begin{aligned}
F_{1 n} & =\frac{\sin \frac{n \pi h_{1}}{h}}{n} \cos \frac{n \pi z}{h}\left\{\left(\frac{n \pi c}{h} \cosh \frac{n \pi c}{h}\right.\right. \\
& \left.\left.+\sinh \frac{n \pi c}{h}\right) \cosh \frac{n \pi y}{h}-\frac{n \pi y}{h} \sinh \frac{n \pi y}{h} \sinh \frac{n \pi c}{h}\right\} \\
& /\left(\sinh \frac{2 n \pi c}{h}+2 \frac{n \pi c}{h}\right) \ldots \ldots \ldots \ldots \ldots \ldots \ldots(19)^{\prime}
\end{aligned}
$$

となる。

実際に测定するのはある標点間の平均ち緩応力である ため, いま標点間距離 $2 c^{\prime}$ に対方石平均ち䌅応力を $\sigma^{\prime} y_{m}$ とすれば， $\sigma_{y_{m}}$ は

$$
\sigma_{y_{m}}^{\prime}=\frac{1}{c^{\prime}} \int_{0}^{c \prime}\left(\sigma_{y}^{\prime}\right)_{z=0} d y
$$




\section{で与えられる。}

したがって

$$
\left.\begin{array}{l}
\frac{h_{1}}{h} \leqq 0.5 \text { のとき } \\
\frac{\sigma^{\prime} y_{m}}{Y}=\frac{4}{\pi} \frac{h}{h_{2}} \frac{c}{c^{\prime}} \sum_{n=1}^{\infty} F_{2 n} \\
\frac{h_{1}}{h} \geqq 0.5 \text { のとき } \\
\frac{\sigma^{\prime} y_{m}}{Y}=\frac{4}{\pi} \frac{h}{h_{1}} \frac{c}{c^{\prime}} \sum_{n=1}^{\infty} F_{2 n}
\end{array}\right\}
$$

ただし

$$
\begin{aligned}
& F_{2 n}=\frac{\sin \frac{n \pi h_{1}}{h}}{n}\left[\left(\cosh \frac{n \pi c}{h}+\frac{2 \sinh \frac{n \pi c}{h}}{\frac{n \pi c}{h}}\right) \sinh \frac{n \pi c^{\prime}}{h}\right. \\
& \left.-\frac{c^{\prime}}{c} \cosh \frac{n \pi c^{\prime}}{h} \sinh \frac{n \pi c}{h}\right] /\left(\sinh \frac{2 n \pi c}{h}+2 \frac{n \pi c}{h}\right) \cdots(21)^{\prime}
\end{aligned}
$$

となる。

真応力に対する測定応力の比 $k$ 上おけば

$$
k=\frac{\sigma_{y_{m}}}{\sigma_{y}}=\frac{4}{\pi} \frac{h}{h_{2}} \frac{c}{c^{\prime}} \sum_{n=1}^{\infty} F_{2 n}
$$

\section{として与えられる.}

ここでは板を完全に切抜く全解放の場合について述べ たが，完全に切抜かず表面近傍のみに溝をきるトレパ二 ングの場合において屯, 溝深さ $g$ が溝間幅 $2 c k$ 比し 大きい場合 (Gunnert の実験では $g / c=6 / 7.5=0.8$ 以 上) $)^{5}$ は上と同一の論議を行なうことができるであるう。

2.3 .2 曲げ拘束のない場合

（16）式の応力分布をフーリエ級数に展開して 2.3 . 1 上同様の計算を実施すれば

$$
\begin{aligned}
\frac{\sigma^{\prime} y}{Y} & =\sum_{n=1}^{\infty}\left[\frac{4}{\pi}\left(1-\frac{\psi}{\varepsilon_{0}}-\frac{h_{1} \phi}{\varepsilon_{0}}\right) \frac{\sin \frac{n \pi h_{1}}{h}}{n}\right. \\
& \left.-\frac{4}{\pi^{2}} \frac{h \Phi}{\varepsilon_{0}} \frac{(-1)^{n}-\cos \frac{n \pi h_{1}}{h}}{n^{2}}\right] F_{1 n} \\
\text { ただし } & \frac{\psi}{\varepsilon_{0}}=-\left\{4+\frac{h_{1}}{h}+\left(\frac{h_{1}}{h}\right)^{2}\right\}\left(\frac{h}{h_{2}}\right)^{2} \frac{h_{1}}{h_{2}} \\
\frac{h \phi}{\varepsilon_{0}} & =6\left(\frac{h}{h_{2}}\right)^{2} \frac{h_{1}}{h_{2}}
\end{aligned}
$$

で与えられ，標点距離 $2 c^{\prime}$ 間の平均ち緩応力 $\sigma y_{m^{\prime}}{ }^{\prime}$ は

$$
\begin{aligned}
\frac{\sigma^{\prime} y_{m}}{Y} & =\frac{c}{c^{\prime}} \sum_{m=1}^{\infty}\left[\frac{4}{\pi}\left(1-\frac{\psi}{\varepsilon_{0}}-\frac{h_{1} \phi}{\varepsilon_{0}}\right) \frac{\sin \frac{n \pi h_{1}}{h}}{n}-\frac{4}{\pi^{2}} \frac{h \phi}{\varepsilon_{0}}\right. \\
& \left.\frac{(-1)^{n}-\cos \frac{n \pi h_{1}}{h}}{n^{2}}\right] F_{2 n} \ldots \ldots \ldots \ldots \ldots \ldots \ldots \ldots \ldots \ldots \ldots \ldots \ldots \ldots
\end{aligned}
$$

となる．真応力に対する測定応力の比 $k$ は

$$
k=\frac{\sigma^{\prime} y_{m}}{Y}
$$

である。

\section{3. 数 值計算}

\section{1 曲げ完全拘束の場合}

Fig. 5 は $2 c / h$ を $1,1 / 2,1 / 4$ 亿変化した場合， $h_{1} / h$ と $z=0$ でのち緩応力（测定応力） $\left(\sigma^{\prime} y_{m}\right)_{z=0}$ の関係を （21）式をもとに計算した綃果であり，(a) は $c^{\prime} / c=0$ の場合，（b）は $c^{\prime} / c=0.6$ の場合である.ここに $c^{\prime} / c$ $=0.6$ は全解放法の代表的方法である Gunnert 法5) K おける值之一致させるために採用した。図中鎖線は(17), (18) 式上り求めた真応力 $\left(\sigma_{y}\right)_{z=0}$ である. Fig. 6 は上 の結果を真残留応力に対する比 $k$ で示したすのであり， 実線が $c^{\prime} / c=0$, 点線が $c^{\prime} / c=0.6$ 亿対する計算值であ る.

以上の結果より $h_{1} / h$ が小さい範圈では測定応力は真 の值より小さいが， $h_{1} / h$ がある限界值より大きくなれ ぼ真値にほぼ一致する（Fig. 6 亿打いて $2 c / h$ が1の 場合，ち髣応力が真值よりもやや大き目になる点がある が，真值との差は約10\%程度であり，かつFig. 5 のよ うにその点では真值が小さいので，真值にほぽ一致する としてよいであるう)，この限界值は $2 c / h$ の大きさに よって異なり, $2 c / h$ が小さい程 $h_{1} / h$ の小さい值で真 值に一致するようになる。的の影響は $c^{\prime} / c$ が 1 亿近づ くにつれ真応力に近づくが，その差は大きなおのではな い.

Fig. 7 は $h_{1} / 2 c$ を模軸によって $k$ を整理したもの で, 実線が $c^{\prime} / c=0$, 点線が $c^{\prime} / c=0.6$ の場合であるが， $h_{1} / 2 c$ 之 $k$ の関係に対しては $2 c / h$ はほとんよ゙影響を与 えないととが示されている. 図より $c^{\prime} / c=0$ の時 $h_{1} / 2 c$ が約0.35 0.40以上, $c^{\prime} / c=0.6$ の時 $h_{1} / 2 c$ が約0.35以上 であればち緩応力法真值に一致し（約10\%の誤差見込 む)，乙の值は板厚 $h$ の影響をさほど受けないというこ とができる。

\section{2 曲げ拘束のない場合}

Fig. 8 は上と同様に $h_{1} / h$ 亡 $k$ の関係を示すすので

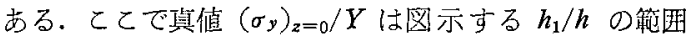
では一定值 1 を示す. Fig. 9 は $h_{1} / 2 c$ と $k$ の関係を示 すものであるが，真値を与える $h_{1} / 2 c$ の限界値（誤差 約10\%）は $h$ に関せずほぼ一定で， $c^{\prime} / c=0$ に対し0.35 $\sim 0.40, c^{\prime} / c=0.6$ に対し約 0.35 となり， 3.1 節の場合と 同様の傾向走し，拘束モーメントの影響は䵵視でき る.

一般の測定においては $c^{\prime} / c$ は0となるととはなく， 約 0.5 程度以上の値をとりうるので，クラッド鋼におい $\tau h_{1} / 2 c$ が約 0.35 以上，すなおち約 $1 / 3$ 以上であれば，表 面の測定応力は板厚に関せず点の応力上ほぼ一致する。 との值はたとえぱ Gunnert 法を採用すれば $2 c=15 \mathrm{~mm}$ 


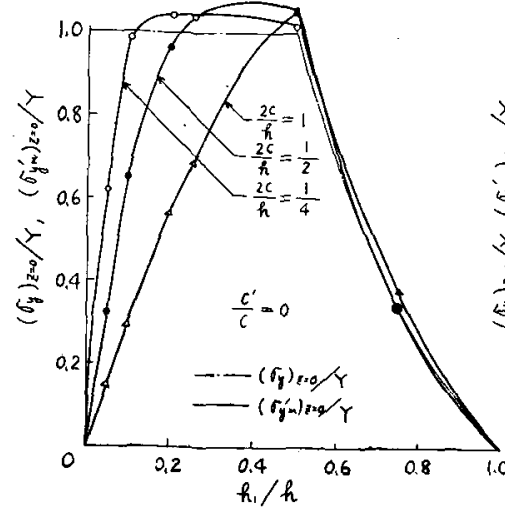

(a)

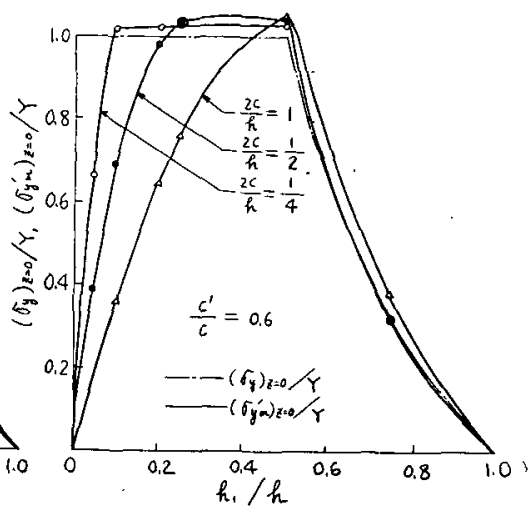

(b)

Fig. 5 Comparison between true stress and relaxed stress by calculation (Completely constrained for bending distorsion)

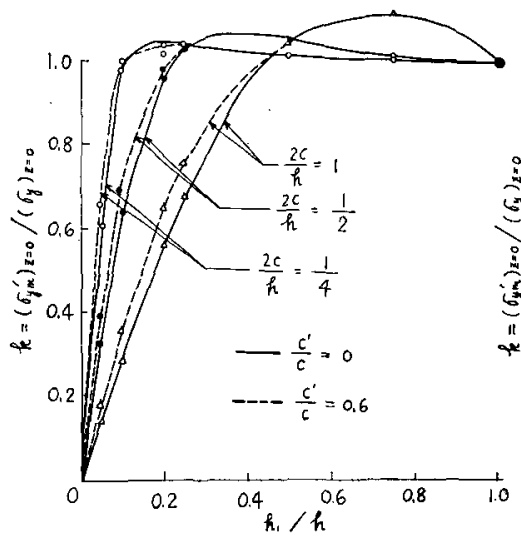

Fig. $B$ Relation between $h_{1} / h$ and $k$ by calculation (Completely constrained for bending distorsion)

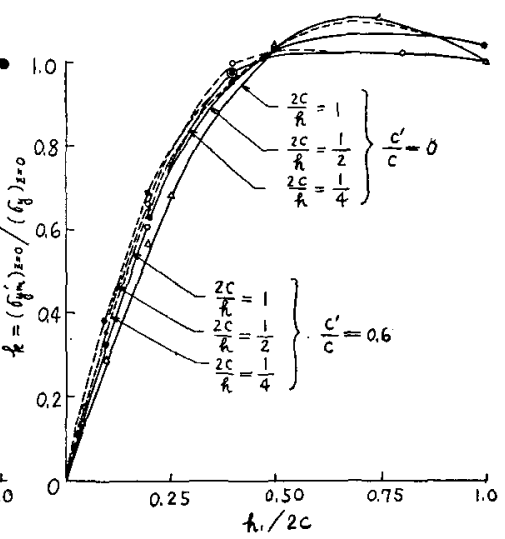

Fig. 7 Relation between $h_{1} / 2 c$ and $k$ by calculation (Completely constrained for bending distrsion)

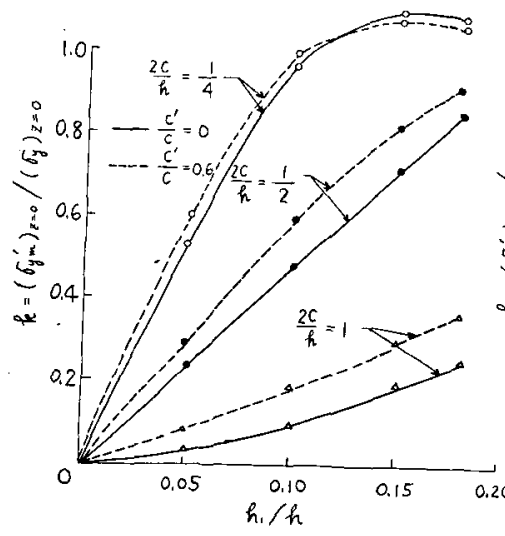

Fig. 8 Relation between $h_{1} / h$ and $k$ by calculation (No constraint)

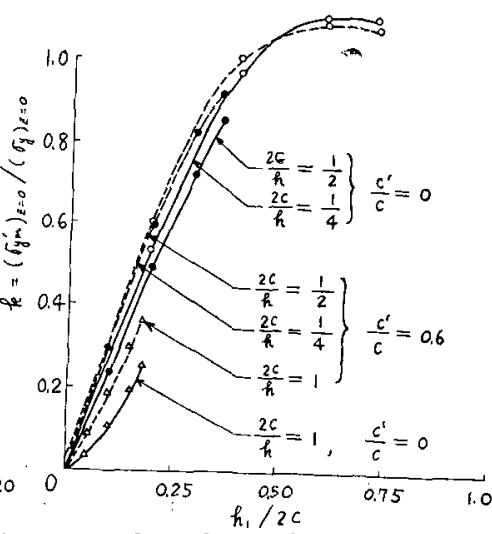

Fig. 9 Relation between $h_{1} / 2 c$ and $k$ by calculation (No constraint)
なるゆえ， $h_{1}>$ 約 $5 \mathrm{~mm}$ て あればほぼ真值が測定される ことになる。

\section{4. 実験的考察}

4. 1 試 臨 片

ステンレスクラッド銅 (SUS 28+SB42B) より Fig. 10 に示す薄く長いく形状平

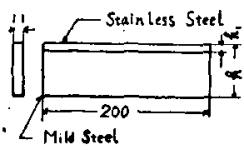

$h . / h=0.03-0.14$ $A=32-60$

Fig. 10 Specimen

板を切出し，ステンレス鋼 部，および軟鋼部の表面を適 当に切削して $h_{\mathrm{y}} / h$ の值を数 段階に変化させたむのを試験 片とした。これに前述のよう な残留応力を与えるため，機 械加工後無拘束状態で $650^{\circ} \mathrm{C}$, 約 3 hr 加熱炉冷を行なった。

\section{2 実験の方法}

板の真の残留応力分布は， $z=h / 2$ の面で試験片を 2 分 割して表面 $(z=0, h)$ の面の ひずみ変化量を測定した後、 おのおのの分割試験片に対し てちく次切削を机てない，ち く次切削による切削反対面の ひずみ変化量を求めて，てれ らの値を基以計算を行なって 推定した.

切抜き，トレパニングによ 石応力緩量在求めるた に，上とは別の試験片につ き，Fig. 11 に示すようにく

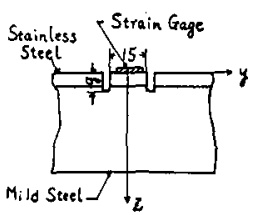

Fig. 11 Contour of cutting groove 
形板の中央 $(\boldsymbol{y}=0)$ ， ステンレス鋼の上面 $(\boldsymbol{z}=0)$ に標 点距離 $5 \mathrm{~mm}$ の抵抗線ひずみゲージをはりつけ，切抜 幅

$$
2 c=15 \mathrm{~mm}
$$

として図のように金切りのこを用いて除々に清を入れ， 㴖深さ $g$ 之表面のひずみの変化量の関係を求めた。こ こで $2 c=15 \mathrm{~mm}$ としたのは前述のでとくGunnert 法 の解放溝の内径敒等しくしたるのである. Gunnert 法 では標点距離が $9 \mathrm{~mm}$ で本実験の標点距離とは異なる が，本実験のはうが短かいためち緩ひずみ量は Gunnert 法より絶対值が小さく測定され，切抜き法またはトレパ ニング法が採用できるステンレス鋼部の厚さの限界值を 求めるには本実験のほうが綮格側にある。しかし前述の ように両者の差は大きなものではなく，ほとんど無視で きるあのと孝えられる.

\section{3 実験結果およびその考察}

Fig. 12 はちく次切削法による初期残留応力の測定例

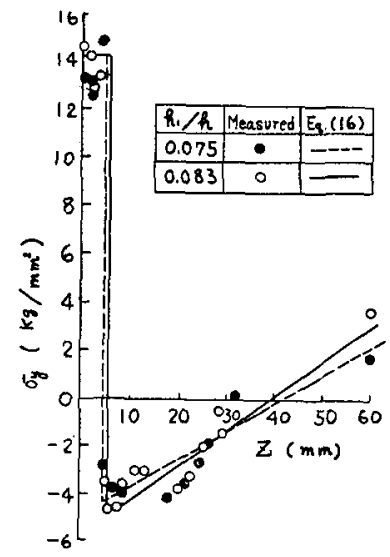

Fig. 12 Examples of measured initial residual stress distribution (No constraint)

である．ての応力分布はいわゆる真の応力分布亡考えら れるもので，ステンレス鋼部においてかなり大きい引張 応力が残留し，軟鋼部の応力心絶対值が小さく，その境 界部沶いて応力が急変しているてとがうかがわれる. また $h_{1} / h$ が実験籍围に変化してもステンレス鋼部の応 力値には大きな变化が見られなかった (図省略). 図中 実線，点線は（16）式に扔いて $Y$ をステンレス鋼部平 均応力に合致するようにして求めた計算結果であり，は ぼ測定結果の特性を示している.

Fig. 13 は Fig. 11 亿示すよう亿灌の深さ $g$ を除々に 增した場合，表面でのち䌊㐫力の測定結果を示したあの である．眓よりわかるごとく $g$ がある値（こてでは $2 c$ $=15 \mathrm{~mm}$ に対して約 6〜8 $\mathrm{mm}$ ）以上になると表面での ち緩応力は一定上なる。図示を省略したがそのち綬応力

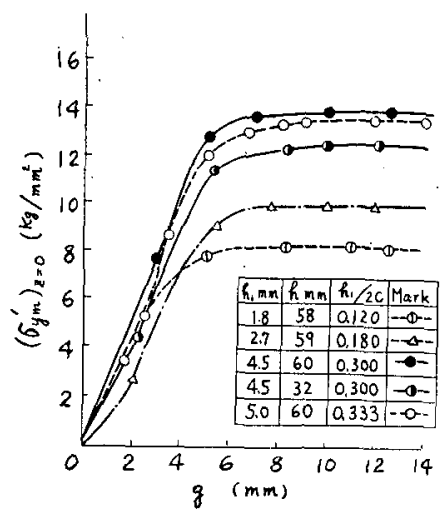

Fig. 13 Relation between measured relaxed stress and depth of cutting groove

は板を完全に切抜いてもはとんど変化しなかった。すな わち完全切抜きの場合について行なった前述の議諭の結 果を部分切抜き（トレパニング）に対して適用してもは ぼ罗当であると考えられる。

Fig. 14 伎真の残留応力を Fig. 12 亿示す平均値 14

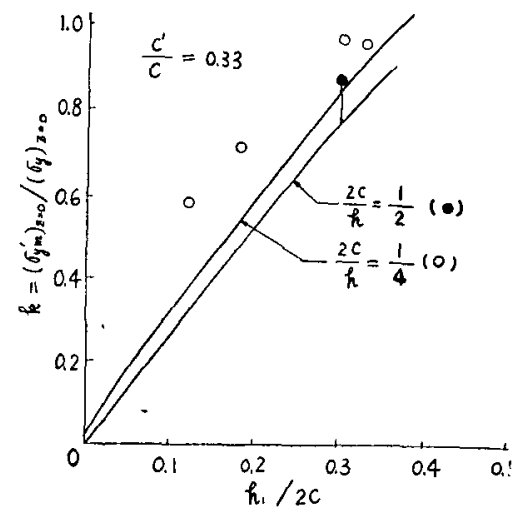

Fig. 14 Measured $k$ values

$\mathrm{kg} / \mathrm{mm}^{2}$ としたときの真応力に対する測定応力の比 $k$ 上 $h_{1} / 2 c$ の関係を示したあのである. $h_{1} / 2 c$ が小さい場 合は測定応力は真応力に対し小さく $h_{1} / 2 c$ 加大き くなるにつれ真応力代近づくことがうかがわれ，本实験 の場合 $h_{1} / 2 c>1 / 3$ でほぼ真值が求められることを示し ている. 図中実線は（25）式化よる計算值 $\left(c^{\prime} / c=5 / 15\right.$ $=0.33$ として $c^{\prime} / c=0$ と $c^{\prime} / c=0.6$ の值より内捕して求 めた）を示すすので，実測值は傾问的には一致している が, $h_{1} / 2 c$ が小さい範囲では実測値のほうが計算値より 大きかった。李わち測定值のほうが計算值より真值

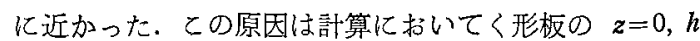
に打滰界条件を完全には満足していないことの影響 （この影響は $h_{1} / 2 c$ が小さい場合が大さいと考えられ る)，あるいは初期残留応力がすべての試験片において 
完全には一致していないための影響なよ゙が考えられるが 末娭討である.しかし測定値のほうが計算值より真值に 近い值を示して扣り，かつち緩応力が真值を示すように なる $h_{1} / 2 c$ の限界值は約 $1 / 3$ 程度であり， $h_{1} / 2 c$ の限界值 に対して計算值がやや厳格側にあることは前述の計算結 果の結論は実用的に十分妥当であると考えられる.

したがってステンレスクラッド銅に打いて $h_{1} / 2 c$ が 約1/3より大きければ表面の応力はほとんど完全にち緩さ れ，切抜き法またはトレパニング法で表面の残留応力を

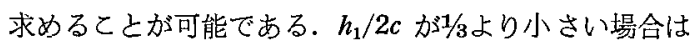
真の応力より小さい. $2 c$ の值としては標点距離の変化 量测定精度の面よりあまり小さくするととはできずある 限度がある. 1/3より小さい場合は表面の応力を求めるに はちく次切削法，あるいはその他の方法を採用すべきで ある。

\section{5. 結'言}

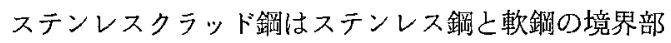
で残留応力が急激に変化する場合が多いが，加る状態 のステンレス鋼表面残留応力を切披き法，あるいはトレ パニング法で测定する場合の测定值の精度につき検討 し，つぎの結果を得た。
(1) 切抜き幅 $2 c$ に対するステンレス鋼部厚さ $h_{1}$ (残留応力が急变するまでの位置) の比 $h_{1} / 2 c$ が約 $1 / 3$ 以上であればステンレス鍓表面の応力はほ上んど完全に ち緩され，切抜き法またはトレパニング法により表面吣 力を求めることができる.

(2) $h_{1} / 2 c$ に対する限界值は標点距離 $2 c^{\prime}$, 板厚 $h$ にはさはご影響をうけない。

(3) $h_{1} / 2 c$ か $1 / 3$ より小さい場合は测定值は真の心力 より小さい.したがってかかる場合に対して表面の残留 応力を求めるにはちく次切削法，あるいはその他の方法 を採用すべきである。

本研究を遂行するにあたり実験に御協力を得た日立製 作所笠戸工場蒲原秀明君に深囬の謝意を表する次第であ る.

\section{参考文 献}

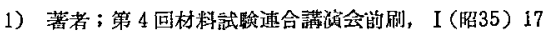

2）著者；機械学会满演会前刷，32（昭35）95

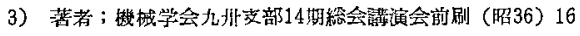

4）木原博，增渕興一；溶接变形上残留応力（昭30） 83

5) R. Gunnert; Residual Welding Stresses (I.I.W. Rep.)

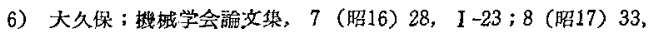
I -185

7) S. Timoshenko; Theory of Elasticity (1951) 29 